\title{
Initial Infection of Falcataria moluccana Leaves and Acacia mangium Phyllodes by Uromycladium tepperianum Fungi in a Laboratory Trial
}

\author{
Siti Muslimah Widyastuti*, Harjono, Zulchan Andika Surya \\ Departement of Silviculture, Faculty of Forestry, Gadjah Mada University, Jl. Agro-Bulaksumur Yogyakarta 55281, \\ Indonesia
}

Received March 23, 2013/Accepted December 15, 2013

\begin{abstract}
Sengon is a fast growing species that is cultivated widely in Indonesia. Lately, sengon is severely attacked by fungus Uromycladium tepperianum that causing gall rust disease. It is also known to attack various types of acacia. This study aims to determine the fungal infection process $U$. tepperianum on sengon leaves and the possibility of infection on Acacia mangium in the laboratory trial. Leave samples and fungal pathogen teliospores obtained from Cangkringan, Sleman, Yogyakarta. Several approach procedures conducted to achieve these objectives were: (1) identification of diseased trees, (2) collecting samples of diseased leaves, branches, twigs, and stems, and (3) artificial inoculation and investigating the infection process of $U$. tepperianum teliospores in the laboratory. The results showed that the process of infection in sengon started by teliospores germination and germ tube formation. Successive germ tube forming penetration pegs. In the plant tissue, the penetration peg formed hypha and further developed into intracellular and intercellular hyphae. The artificial inoculation on A. mangium leaf surface showed few spores can germinate. However, none of them managed to penetrate.
\end{abstract}

Keywords: Uromycladium tepperianum, sengon, acacia, gall rust, infection

\begin{abstract}
Abstrak
Sengon merupakan tanaman cepat tumbuh yang dibudidayakan di Indonesia. Namun, akhir-akhir ini banyak sengon yang menderita penyakit karat tumor sangat parah. Penyakit ini disebabkan oleh jamur Uromycladium tepperianum, juga diketahui menyerang berbagai jenis tanaman akasia. Penelitian ini bertujuan mengetahui proses infeksi jamur U. tepperianum pada daun sengon dan kemungkinan infeksinya pada Acacia mangium di laboratorium. Sampel dan teliospora jamur patogen didapatkan dari Cangkringan, Sleman, Yogyakarta. Beberapa pendekatan yang digunakan untuk mencapai tujuan tersebut adalah: (1) identifikasi pohon yang sakit, (2) pengumpulan contoh berupa daun, cabang, ranting, dan batang yang sakit, serta (3) inokulasi buatan dan proses infeksi U. tepperianum di laboratorium menggunakan teliospora U. tepperianum. Hasil penelitian menunjukkan bahwa proses infeksi pada tanaman sengon diawali dengan perkecambahan teliospora dan pembentukan buluh kecambah. Buluh kecambah selanjutnya membentuk pasak penetrasi. Di dalam jaringan tanaman, pasak penetrasi membentuk hifa dan berkembang menjadi hifa intraseluler dan interseluler. Hasil uji inokulasi buatan pada permukaan daun A. mangium menunjukkan sebagian kecil spora dapat berkecambah. Namun, tidak ada yang berhasilmelakukan penetrasi.
\end{abstract}

Kata kunci: Uromycladium tepperianum, sengon, akasia, karat tumor, infeksi

*Correspondence author, email:smwidyastuti@ugm.ac.id, tel.:+62-274-512102

\section{Introduction}

Sengon (Falcataria moluccana (Miq.) Barneby \& JWGrimes) is a well-known tree in the smallholder plantation, particularly in Java. It is a fast growing tree that has diverse use of its timber. It is provide raw material for several industries such as pulp and paper production, plywood, fiber-board, and block-board. Given the high economic value and the ease of management, the cultivation of sengon is increased (Atmosuseno 1998). As a fast growing tree it can height up to $45 \mathrm{~m}$ with diameter up to $100 \mathrm{~cm}$ over 25 years. At the age of 6 years sengon plantations can produce as much as $372 \mathrm{~m}^{3}$ of logs ha ${ }^{-1}$, so it is described as a miracle tree (Atmosuseno 1998).

Natural distributions of sengon are ranging from Maluku, Papua New Guinea, Bismark Islands, to the Solomon Islands. However, currently sengon widely planted in tropical climate area (Soerianegara \& Lemmens 1994). Sengon does not require complicated requirements to grow. Sengon has ability to grow on a variety of soil types, ranging from poor to well drainated soil, and from marginal land to soil that rich of nutrients. In Brunei and Malaysia, sengon can grow in saline, dry, and moist soils. It grows well in the altitude 
ranging $0-1,500 \mathrm{~m}$ asl. However, optimal growth of sengon obtained when planted in nutrients rich soil with good texture and structure (Atmosuseno 1998). Best soil for sengon is the soil with pH 6-7. Sengon is a tropical tree species that will grow well at a temperature of $18-27^{\circ} \mathrm{C}$ with a humidity of $50-75 \%$. Sengon prefers to expose to sufficient amount of sunlight, therefore it should be planted in the open land (Santoso 2000).

In the addition to sengon, Acacia mangium was also used in this study. It is a fast growing tree that harvested between 8 to 10 years old (Joker 2001). Natural distribution of $A$. mangium includes Sulawesi, Seram, Aru Island, Papua, Papua New Guinea, and northeastern Queensland (Lemmens \& Soerianegara 1995). Distribution of these plants is strongly influenced by rainfall and soil drainage. $A$. mangium optimally grows on an altitude of 100-780 m asl. It is a pioneer species in lowland rain forest, critical land and dry land with a low $\mathrm{pH}$ (4.5-6.5). It is also grow in the lands close to mangroves, in the seasonal swamps, along rivers side, dry plains, hills, and in the mountain-foot (Awang \& Taylor 1993).

A. mangium can reach up to $30 \mathrm{~m}$ height with the clear boles can be more than half of its height. It has rough surface, grooved longitudinally, and the color varies from pale grey brown to brown. Buttress roots are sometimes found at the base of the trunk (Turnbull 1986). Although there are no reports of $U$. tepperianum attacks on $A$. mangium to date, but as an invasive species, its stands are susceptible to various diseases.

Currently sengon has gain wide interest among small timber companies and smallholder farmers to cultivate it. To our knowledge, an extensive cultivation of limited species which tend to single type cultivation (monoculture) is prone to the development of plant pests and diseases. It has a great possibility to develop into epidemic (Wiryadiputra 2007).

One of the problems that have arisen with the extensive cultivation of sengon at the moment is the outbreaks of gall rust disease that caused by a fungus Uromycladium tepperianum. It can cause the death of sengon from seedlings to the stands (Rahayu et al. 2009; Anggraeni et al. 2010; Rahayu et al. 2011). The gall rust disease has also been reported caused huge losses to sengon plantation owned by government, private, and smallholders in Philippines (Braza 1997), East Timor (Old 2003), and Malaysia (Lee 2004). The fungi also attacks sengon which provide shade for coffee plantations in East Timor and causing damage to coffee plants as the shade trees are damaged or even dead (Old 2003).

The gall rust disease rapidly disperses by the wind and no proper and effective way to control it to date. Several studies abroad indicate that the fungus $U$. tepperianum can also infect various types of acacia (Old et al. 2000). Acacia mangium is a species that grow widely in Indonesia. Both private and state plantation industry in Indonesian have planted several types of acacia as a component of industrial plantation forest (HTI) including A. mangium. It is feared that this species may also be infected by the U. tepperianum. This research was conducted to determine the initial infection of $U$. tepperianum sengon leaf and the possibility of fungal infections of U. tepperianum on A. mangium phyllodes.

\section{Methods}

Preliminary observation of $U$. tepperianum attacts in sengon was performed in sengon community plantation forest (hutan rakyat) in Wonosobo, Central Java, while the sample of diseased stems, branches, twigs, and leaves were collected from sengon community plantation forest in Cangkringan, Sleman, Yogyakarta. The further procedures of study were performed in the Laboratory of Forest Protection and Health, Faculty of Forestry, Gadjah Mada University.

Diseased tree identification Identification was conducted by observing and recording the trees in the field that show symptoms and signs of disease. Symptom of enlargement of size was observed on the stem, branches, twigs, and leaves. The formation of dark brown spores mass (powdery spores) was also observed.

Sample collection Sampling of diseased trees in the field was conducted by cutting the leaves, branches, twigs, and stems which indicate the presence of a gall using a scissors or a hand saw. The samples were then kept in a paper envelope and marked with a permanent marker. Samples were protected from wilting by avoiding hot condition and immediately taken to the laboratory for further observation. Leaf and phyllode were selected as a material for inoculation as it is easy to collect and to observe. However, the leaf sample was provides only single observation opportunity since it can not be observed furthermore if the tissues had died.

The infection process of $\boldsymbol{U}$. tepperianum $U$. tepperianum produced a single type of spores called teliospores (Rahayu 2008). Teliospores found on the surface of the gall were removed by a small brush and placed in a petridish. The teliospores were dissolved in sterile water that contains Tween-20 (0.02\%). Tween-20 will saturate binding sites on water surfaces and helps teliospores stick to the surface of plant organs. Teliospores concentration was $1 \times 105$ spores $\mathrm{mL}^{-1}$. Teliospores suspensions were then inoculated on leaves of sengon seedling and phyllodes of $A$. mangium using a soft brush. Inoculated seedlings were placed in a container to maintain the humidity and temperature was kept between of 25-30 ${ }^{\circ} \mathrm{C}$ for 96 hours (modified Morris 1987). The treatment was applied to 4 months old seedlings of sengon and $A$. mangium, each treatment contains 6 seedlings.

Observations and image is taken at 2, 24, 48, 72, and 96 hours after teliospores inoculation. Twenty leaves of sengon and 5 phyllodes of $A$. mangium that had been inoculated with teliospores solution were taken for each observation. For $A$. mangium, phyllodes were cut into $1 \mathrm{~cm}^{2}$ for ease treatment and observation. Samples were placed in a $50 \mathrm{~mL}$ Erlenmeyer flask that contains $20 \mathrm{~mL}$ of $96 \%$ ethanol. Samples in ethanol solution were then boiled for 20 minutes to remove the chlorophyl (Ruzin 1999), then $96 \%$ ethanol was removed and replaced with chloral hydrate $\left(2.5 \mathrm{~g} \mathrm{~mL}^{-1}\right)$, followed by another heating for 20 minutes until the sample becomes transparent (Elliott et al. 2008). To obtain a crosssectional sample, the leaf was longitudinally cut using a microtome. 
A model of infection process of $U$. tepperianum to plant species can be studied using some selected leaf for the artifial inoculation. In this study, A. mangium was selected in addition to sengon. The morphology of thin leaves provides better of observation, through the upper surface of the leaves as well as on the cross section. The relatively large number of leaves on sengon and A. mangium also provides enough samples for observation and reduces the number of seedling required to perform the experiment. The multiple layers of leaf tissue and the presence of stomata on the leaf surface provide a clear image of the infection process occurred.

Observation of inoculated samples was conducted using Olympus CX31 microscope. Leaf sample was placed on glass objects and stained with laptophenol trypan blue using a pipette. The image of microscope observation was recorded using a MDCE-5A digital camera that connected to a computer that installed with ScopePhoto version 2.0.4 software.

The number of teliospores that germinate and penetrate to 5 leaves of sengon and 5 phyllodess of $A$. mangium was counted to determine the tendency (trend) of germination and penetration in the leaves of 2 species used in this study. The observed teliospores were grouped into 3 categories, i.e.; non germinated teliospores, germinated teliospores, and penetrated teliospores.

\section{Results and Discussion}

Symptoms and signs of gall rust disease of sengon in the field Sengon is a susceptible plant to attack by pathogens, such as fungi Ganoderma sp. (Herliana et al. 2012), Oidium sp., and U. tepperianum. This tree is highly cultivated by community and government companies in the sampling location in Cangkringan. Sengon stands in this site are showing symptoms and signs of disease in nearly all of the trees (Figure 1).

Gall rust disease found in sengon stands is identified caused by $U$. tepperianum. It is a rust fungi that causes gall forming and attacks several types of Acacia spp. $U$. tepperianum is a native Australian fungus that was introduced to South Africa as a biological control agent in 1987 (Wood 2012). It was used to control Acacia saligna in South Africa, with no expectation to attack other plant species (Morris 1997; Mehta 2000). However, it was contrary to the results of study conducted in Philippines that U. tepperianum was attacked sengon (Braza 1997). It was also causing outbreaks in sengon plantation in Sabah, Malaysia (Lee 2004) and attacked sengon that serves as shade tree in coffee plantations in East Timor (Old 2003). The symptoms of this disease in sengon notice by a gall that locally found in the infected trunk, branches, twigs, leaves, and stalks. U. tepperianum has small pycnium, blackish brown color, globose with a diameter of $150 \mu \mathrm{m}$, spermatia hyaline, and ellipsoid shape. Galls grow from less than $1 \mathrm{~cm}$ in diameter to about $10 \mathrm{~cm}$, the swelling of the trunk and branches can even greater than $18 \times 6 \mathrm{~cm}$ with a reddish brown color to dark brown. Gall shape varies from round to irregular. The young galls are green (Figure $2 b$ ) and develop further until it all covered up with a layer of reddish brown rust powder (Figure 2e). The powdery layer is a deposit of teliospores, which is a sign of this disease. Teliospores composed of a cluster of three probasidial cells that are located at top of a single pedicel, depressed between globoses, with reddish light brown color, vertical thick striate, crenulate margin. The thickness of spore wall is 2-3 $\mu \mathrm{m}$, with up to $5 \mu \mathrm{m}$ thickness in the apex. The length of teliospores is between 14-22 $\mu \mathrm{m}$ and $18-25 \mu \mathrm{m}$ width. It has one apical germ pore, pedicel hyaline, septate, and deciduous (USDA 2007). If the disease hit the petiole, it will cause petiole to bend due to the thickening and swelling, the leaf will curl and eventually shed.

A leaf sample infected by $U$. tepperianum shows symptoms of disease with discoloration and changes in shape by curling in one side of leaf margin because of swelling (Figure 2a). This is consistent with Lee's study (2004) that discoloration and deformation are the symptoms of gall rust diseases. Figure $2 \mathrm{~b}$ shows that infection occurs in the petiole, which is analogous to a research by Wiryadiputra (2007), the infected petiole was swollen and bent irregularly, it will ended up with yellowing and casting of the leaves. Swelling and curling was also occurs in the infected twigs (Figure 2c). Figure $2 \mathrm{~d}$ and $2 \mathrm{e}$ show the swelling that occurs in the main stem of the plant. The diameter of gall in the branch and trunk can be $>5 \mathrm{~cm}$. Usually in the larger gall teliospores are more abundance and noticed by reddish brown powder (Wiryadiputra 2007).

In the most of the pathogenic fungi, spores are their propagules that widely spread by several factors such as wind, insects, birds, and humans (Agrios 2005; Triyogo \& Widyastuti 2012). Spores of U. tepperianum disperse widely as the wind will easily blow them out. Insects also serve as vectors of gall rust disease. In a study conducted by Triyogo \& Widyastuti (2012) it was revealed that 5 orders of insects (Hemiptera, Diptera, Hymenoptera, Coleoptera, and Lepidoptera) were associated with galls in sengon. This study also recognized that lepidoptera helps the spread of $U$. tepperianum spores. Another study has discovered that the old galls usually have holes as it inhabited by insects and turn black as they were experienced decay (Anggraeni \& Santoso 2003).

Early infection of $\boldsymbol{U}$. tepperianum on sengon leaves in the laboratory Infection is one of the important things in the disease process. Infection in older plants generally resulted in alteration of plants form and may reduce its vigor, while in seedlings and young plants it may resulting death (Edmonds et al. 2000; Rahayu et al. 2010; Triyogo \& Widyastuti 2012). According to Siddiqui et al. (2009), the ability of a pathogen to infect mature plants was lower than in young plants. Previous studies stated that severity of infection declines with decreasing density of the host (Wood 2012). $U$. tepperianum is a rust fungus that produces single microcyclic spores. The mycelium forms pycnia that finally produces teliospores (Wiryadiputra 2007). An obligate fungus such as rusts can not grow on artificial media (Perfect \& Green 2001). Therefore, teliospores for pathogenicity test were collected directly from sengon stems infected by $U$. tepperianum (Figure 3). To observe the process of the initial infection of $U$. tepperianum leaves were selected as materials for artificial inoculation. 
Observations at 2, 24, 48, 72, and 96 hours after inoculation found that teliospores inoculated on sengon leaf surface were able to germinate and penetrate. Figure 4 shows the development of teliospores germination and penetration, after two hours of inoculation teliospores on sengon leaf surface do not show any progressions (Figure 4).

Observation of the samples after 48 hours of inoculation (Figure 4b) shows that teliospores on the leaves surface were germinated and formed a germ tube that extends to the surface of the leaf, Germ tube is then developed into penetration pegs. According to Agrios (2005), penetration pegs generally have a smaller diameter than normal hyphae. If the penetration peg successfully entered into the plant tissue, it will return to the same diameter as normal hyphae. The penetration pegs which penetrate directly on the epidermal cells wall of leaf surface will form vesicles in the epidermal cells. The result is analogous to research by Morris (1987) that used teliospores collected from A. saligna organs infected by gall rust disease as inoculums and inoculated them on various species of acacia.

In further developments, the vesicles were formed hyphae in epidermis cells (Figure 4c). The hyphae penetrate into inner epidermis cell wall and then form the intercellular hyphae (Figure 4d). According to Morris (1987), these intracellular hyphae then headed to transporter tissue through the mesophyll tissue. In natural infections, teliospores formed basidiospores at the beginning then form penetration pegs and finally penetrates the plant tissue. During the natural infection process in sengon, $U$. tepperianum teliospores on the leaf surface were germinated to form basidiospores. In favorable conditions i.e. high relative humidity $(\geq 90 \%)$, basidiospores were formed at 10 hours after inoculation and 6 hours after the penetration pegs were formed and directly penetrate the cells in the epidermal layer of the host (Rahayu et al. 2010). The differences of infection process may be caused by the differences in the environmental conditions.

\section{The development of $\boldsymbol{U}$. tepperianum teliospores on sengon} leaves and $\boldsymbol{A}$. mangium phyllodes The observation of the development of teliospores of $U$. tepperianum on the sengon leaf surface and A. mangium phylodia performed in the laboratory are presented in Figure 5 . In the observation of sengon leaves at 24 hours after inoculation, 145 out of 640 teliospores were found germinated, and only 87 spores were penetrated. While the observation at 48 hours after inoculation found 182 out of 721 teliospores germinated and 103 teliospores were penetrated.

In the observation at 72 hours after inoculation, 195 out of 826 teliospores were germinated and only 128 spores were penetrated. In this study the development of teliospores on sengon leaves tends to increase by hours of inoculation, both the number of germinated and penetrated teliospores, although there were some teliospores still unable to germinate. According Widyastuti et al. (2005), the failure of teliospores to germinate during inoculation generally caused by the presence of inhibitory compounds that formed during the process of sporulation. Observations on the fourth day were unable to be undertaken due to the abundance of germ tubes and penetration pegs that grow on the leaves surface.
They were causing obstruction to the observations and causing no accurate data will be obtained.

In contrast to the results of teliospores observed on sengon leaves, teliospores in $A$. mangium phyllodes observed at 24 hours after inoculation found out a total of 1,954 teliospores in the phyllodes surface, but no teliospores were germinated and penetrated. In the observation at 48 hours after inoculation found 81 out of 4,276 teliospores germinate, but none were able to penetrate. In the observation at 72 hours after inoculation found 110 out of 2,961 teliospores were germinated and again none of the teliospores were penetrated. In the samples observed 96 hours after inoculation found 181 out of 4,309 teliospores were germinated and none of the teliospores were penetrated. The results indicated that the number of teliospores germinated in $A$. mangium phyllodes also tends to increase with time, while the penetration was never occur. Previous studies conducted by Morris (1987) on A. mangium using teliospores collected from of Acacia implexa as inoculum, indicates that there was a resistant reaction causing the growth of hyphae were stopped. Germinating teliospores were surrounded by necrosis and chlorosis, and no galls were formed.

Figure 6 shows the failure of infection of teliospores in $A$. mangium phyllodium. The teliospore in A. mangium phyllodium surface was germinated and formed a germ tube (Figure 6a). The germ tube invades the tissue surface and develops penetration pegs. However the epidermis of $A$. mangium phyllodium has a thick layer of wax (Awang \& Taylor 1993), which provides an initial defense and prevent pathogens to penetrate the surface of the phyllodium. The wax coating provides protection to plants from pathogen penetration.

Penetration pegs were formed on the surface of phyllodes of $A$. mangium (Figure $6 \mathrm{~b}$ ). The formation of penetration peg generates a signal that can be recognized by $A$. mangium to activate the natural defense response of plant. Yellowish brown color at the penetration site suggests a defense reaction of $A$. mangium. The defense alleged to be the accumulation of phenolic compounds, according Lattanzio et al. (2006) which states that if the outer defenses of the plant is unable to stop the infection process of the pathogen, the plant will respond by increasing phenolic content at the site of infection to create unfavourable conditions for further infection process. The series of self-defense shown by $A$. mangium is a non-host resistance. $U$. tepperianum only need one single host to finish whole life cycle which is sengon (Rahayu 2008). In addition to the infection process that does not occur in $A$. mangium, this study suggests the small possibility of $U$. tepperianum attacking $A$. mangium.

\section{Conclusion}

Initial infection of $U$. tepperianum as a result of artificial inoculation on sengon leaves in a laboratory trial begins with direct penetration of penetration pegs to epidermal cells of host plant. Once infection occurs, the penetration peg produces vesicles and hypha inside plant tissue. An artificial inoculation of teliospores on A. mangium phyllodes showed that infection does not occur. 


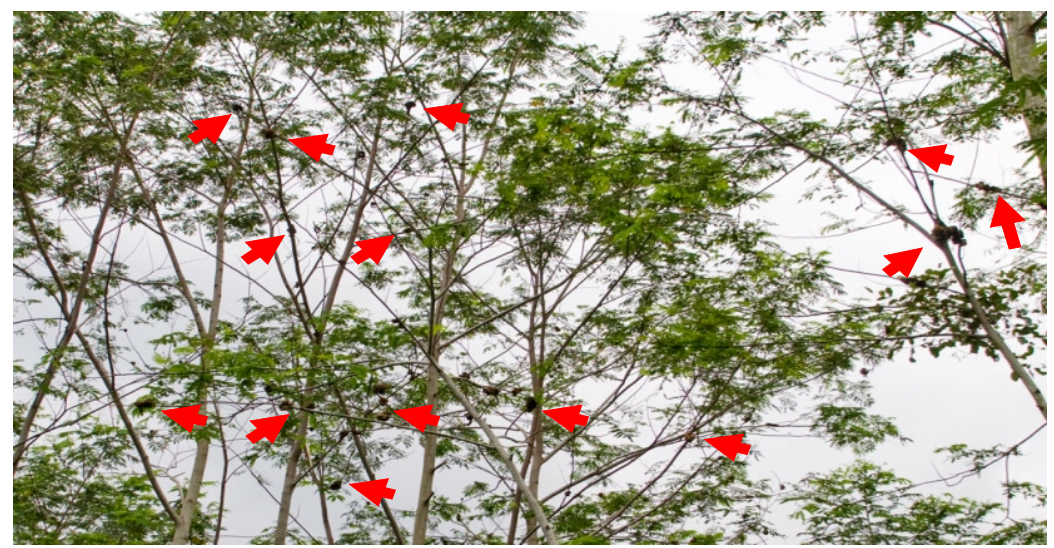

Figure 1 Sengon infected by Uromycladium tepperianum in the community forest stand. Red arrows show the gall rust in the branches.

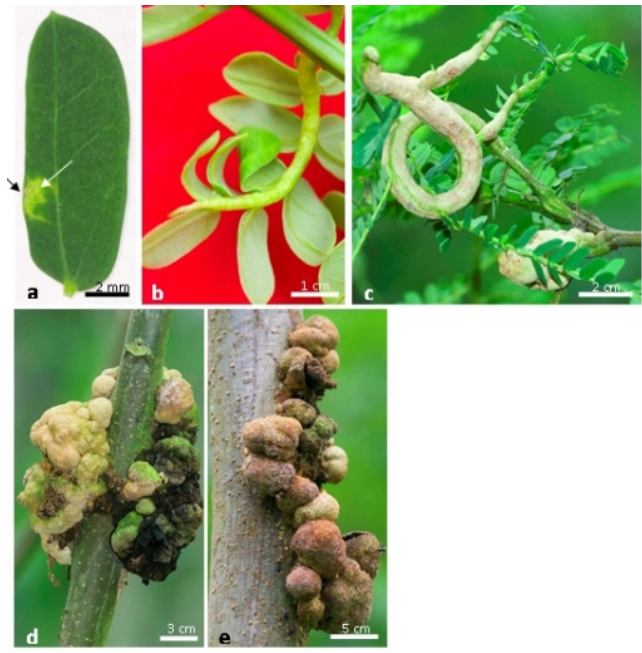

Figure 2 Symptoms of gall rust diseases at sengon organs: (a) leaves, (b) leaf stalks, (c) branches, (d) and (e) trunk.

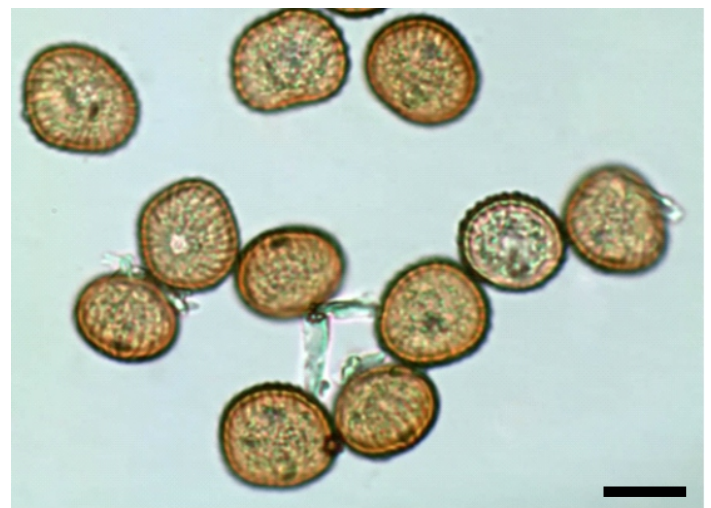

Figure 3 Teliospores of Uromycladium tepperianum, collected from trunk surface of sengon showing gall rust. These teliospores were used as inoculum source for artificial inoculation study on sengon leaves.
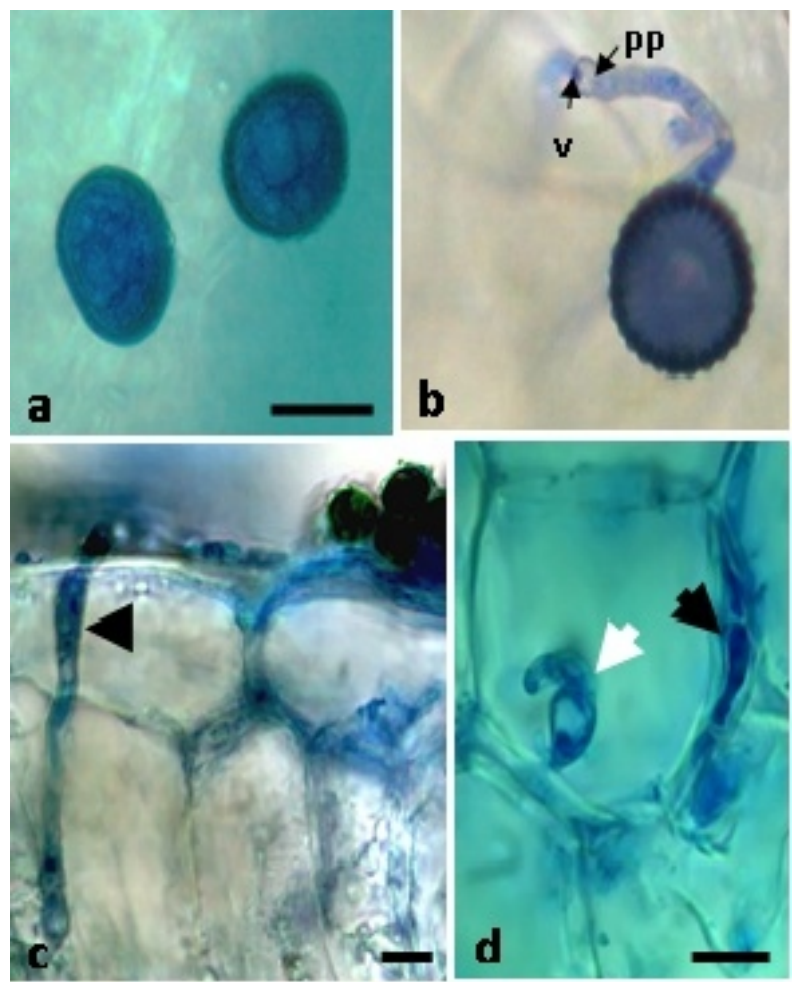

Figure 4 Infection process of Uromycladium tepperianum on sengon leaves by artificial inoculation. (a) Teliospores on leaf surface (2 hours after inoculation), (b) germinated teliospore (24 hours after inoculation) pp: penetration peg, v: vesicle. (c) Direct penetration of intracelular hyphae (black arrow) (48 hours after inoculation), (d) intracelular hyphae (white arrow) dan intercelular hyphae (black arrow) on spongy mesophyll (96 hours after inoculation). Figure (a) and (b) are observed on leaf surface, (c) and (d) are observed from longitudinal cross section of leaf. All samples were stained with lactophenol trypanblue. Bars are representing $10 \mu \mathrm{m}$ lengths. 


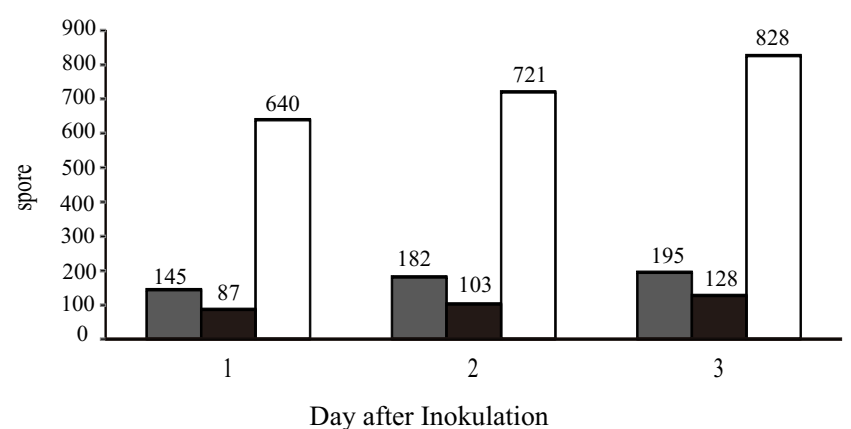

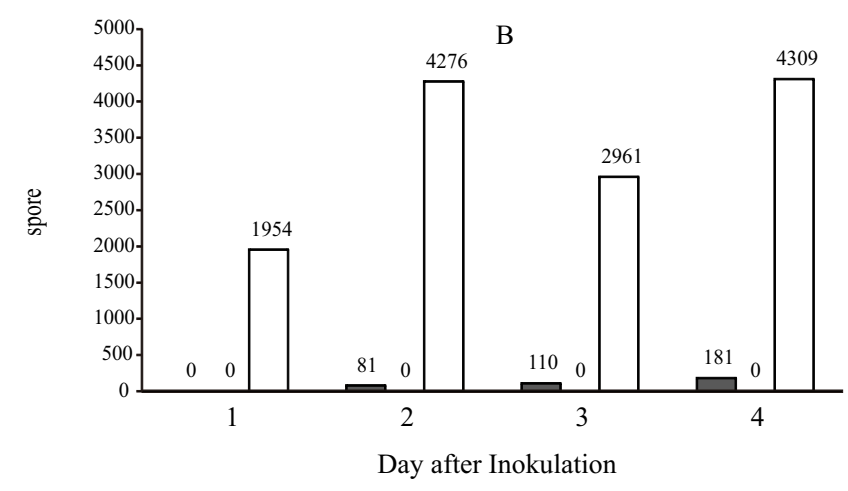

Figure 5 The number of germinated and penetrated teliospores on: (a) sengon leaves, (b) Acacia mangium phyllodium. Total germinated $(\square)$, total penetrated $(\square)$, total teliospora $(\square)$
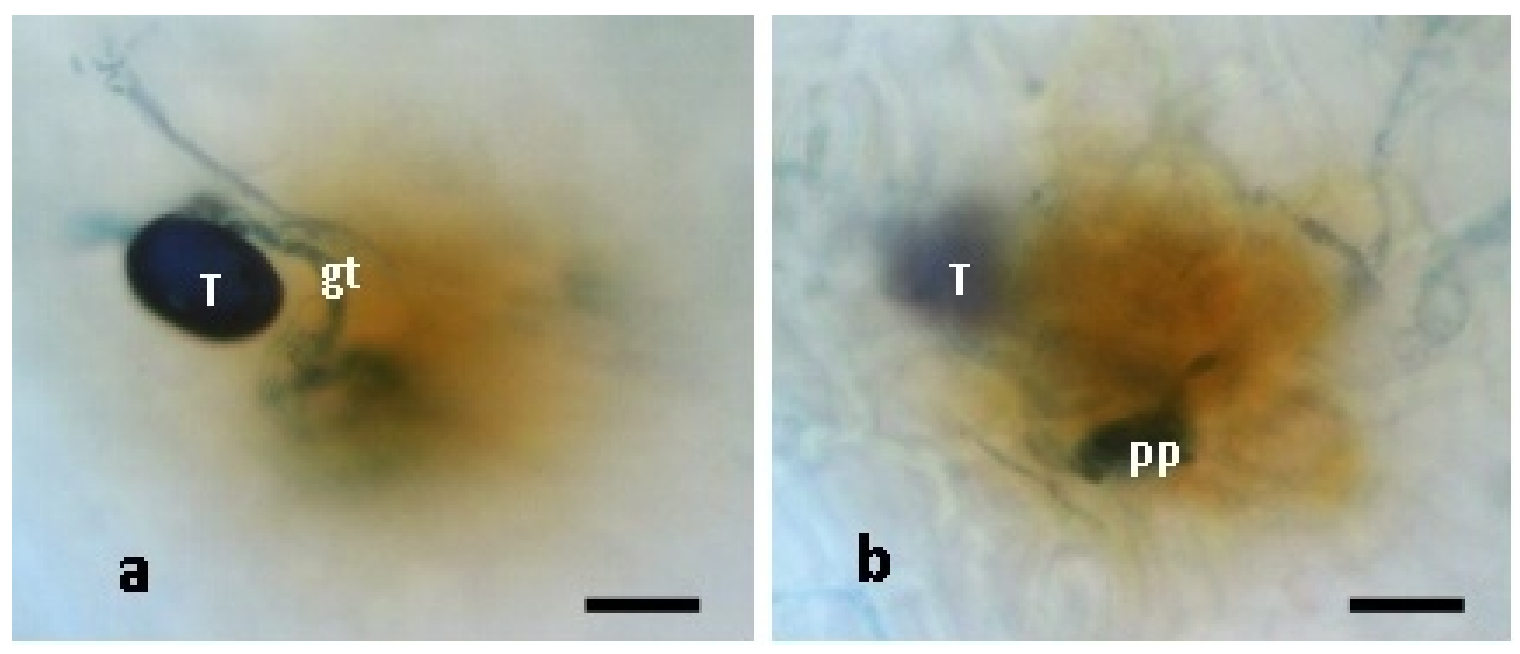

Figure 6 The final of infection process of Uromycladium tepperianum on surface of Acacia mangium phyllodium 2 days after inoculation, (a) and (b) are the same object observed by different focus under microscope. T: teliospore, gt: germ tube, pp: penetration peg. Brown color surrounding infection site are assumed as phenolic compound deposit. Sample is stained with lactophenol trypan-blue. Bars are representing $10 \mu \mathrm{m}$ lengths.

\section{Acknowledgement}

This research was funded by HIBAH BERSAING Year 2010 number of $235 / \mathrm{SP} 2 \mathrm{H} / \mathrm{PP} / \mathrm{DP} 2 \mathrm{M} / \mathrm{III} / 2010$, dated of March 1,2010. The second author is a principal researcher in this project. The third author is a student of the Faculty of Forestry who uses most of this research data for thesis completion.

\section{References}

Agrios GN. 2005. Plant Pathology. Fifth edition. London UK: Elsevier Academic Press.

Anggraeni I, Dendang B, Lelana NE. 2010. Control of gall rust disease (Sacc.) Mc. Alpinon sengon tree (Miq.)
Barneby \& J.W. Grimes) in Panjalu, Ciamis, West Java. Jurnal Penelitian Hutan Tanaman 7(5):273-278.

Anggraeni I, Santoso E. 2003. Penyakit karat puru pada sengon (Paraserianthes falcataria) di Pulau Seram. Buletin Penelitian Hutan 636:1-9.

Atmosuseno BS. 1998. Budidaya, Kegunaan, dan Prospek Sengon. Jakarta: Penebar Swadaya.

Awang K, Taylor D. 1993. Acacia mangium Growing and Utilization. Bangkok: Winrock International and Food and Agriculture Organization of The United Nations.

Braza RD. 1997. Gall rust disease of Paraserianthes 
falcataria in the Philippines. Forest, Farm and Community Tree Research Reports 2:61-62.

Elis NH, Darmono T, Hayati M. 2012. Root diseases Ganoderma sp. on the sengon in West Java and East Java. Jurnal Manajemen Hutan Tropika 18(2):100109. http://dx.doi.org/10.7226/jtfm.18.2.100.

Elliott CE, Harjono, Howlett BJ. 2008. Mutation of a gene in fungus Leptosphaeria maculans allows increased frequency of penetration of stomatal apertures of Arabidopsis thaliana. Molecular Plant (3):471-481. http://dx.doi.org/10.1093/mp/ssn014.

Edmonds, RL, Agee JK, Robert IG. 2000. Forest Health and Protection. New York: Mc Graw Hill.

Lattanzio V, Lattanzio VMT, Cardinali A. 2006. Role of phenolics in the resistance mechanisms of plants against fungal pathogens and insects. Phytochemistry: 23-67.

Lee SS. 2004. Diseases and potential threats to Acacia mangium plantation in Malaysia. Unasylva 217:31-35.

Lemmens RHMJ, Soerianegara I. 1995. Plant Resoures of South East Asia 5 (2) Timber Trees: Minor commercial Timbers. Bogor: Prosea Foundation.

Mehta S. 2000. The invasion of South Africa fynbos by an australiant immigrant: the story of Acacia saligna. Student Online Journal (6):1-10.

Morris MJ. 1987. Biologi of the acacia gall rust, Uromycladium tepperianum. Plant Pathology (36):100-106. http://dx.doi.org/10.1111/j.1365-3059. 1987.tb02183.x.

Morris MJ. 1997. Impact of the gall-forming rust fungus Uromycladium tepperianum on the invasive tree Acacia saligna in South Africa. Biological Control (10):75-82. http://dx.doi.org/10.1006/bcon.1997. $\underline{0560}$.

Joker D. 2001. Informasi Singkat Benih: Acacia auriculiformis Cunn. ex Benth. Jakarta: Direktorat Perbenihan Tanaman Hutan.

Old KM, See LS, Sharma JK, Yuan ZQ. 2000. A Manual of Diseases of Tropical Acacias in Australia, South-East Asia and India. Jakarta: Center for International Forestry Research (CIFOR).

Old KM, Cristovao CS. 2003. A rust epidemic of the coffe shade tree (Paraserianthes falcataria) in East Timor. ACIAR Proc 13:139-145.

Perfect SE, Green JR. 2001. Infection structures of biotrophic and hemibiotrophic fungal plant pathogens. Molecular Plant Pathology 2:10-108. http://dx.doi.org/10.1046/j.1364-3703.2001.00055.x.

Rahayu S. 2008. Penyakit karat tumor pada sengon. Makalah Workshop Penanggulangan Serangan Karat Puru pada Tanaman Sengon. Yogyakarta: Balai Besar Penelitian Bioteknologi dan Pemuliaan Hutan.

Rahayu S, Lee SS, Shukor NAA. 2010. Uromycladium tepperianum, the gall rust fungus from Falcataria moluccana in Malaysia and Indonesia. Mycoscience (51):149-153. http://dx.doi.org/10.1007/S10267-0090022-2.

Rahayu S, Shukor NAA, Lee SS, Shaleh G. 2009. Responses of Falcataria moluccana seedlings of different seed sources to inoculation with Uromycladium tepperianum. Silvae Genetica (58):1-2.

Rahayu S, Widiyatno, Adriyanti DT. 2011. Pengendalian terpadu penyakit karat tumor pada tanaman sengon (Paraserianthes falcataria) di Hutan Rakyat, Kecamatan Pringsurat, Temanggung, Jawa Tengah. Jurnal Ilmu Pengetahuan dan Teknologi Tepat Guna Universitas Gadjah Mada I(1).

Ruzin SE. 1999. Plant Microtechnique and Microscopy. USA: Oxford University Press.

Santoso HB. 2000. Budidaya Sengon. Yogyakarta:Kanisius.

Sidiiqiu I, Bajwa R, Javaid A. 2009. Some factors affecting the pathogenicity of Alternaria alternata against the weed Rumex dentatus. The Philippine Agricultural Scientist (92):282-289.

Soerianegara I, Lemmens RHMJ. 1994. Plant Resourses of South-East Asia No. 5 (1) Timber Trees: Major Commercial Timbers. Bogor: Prosea Publisher.

Triyogo A, Widyastuti SM. 2012. Peran serangga sebagai vektor penyakit karat puru pada sengon (Albizia falcataria L. Fosberg). Jurnal Agronomi Indonesia 40 (1): $77-82$

USDA. 2007. Invasive and Emerging Fungal Pathogens. Uromycladium tepperianum on Acacia spp. http://nt.ars-grin.gov/taxadescriptions/factsheets /index.cfm?thisapp=Uromycladiumtepperianum $[12$ Agustus 2012].

Widyastuti SM, Sumardi, Harjono. 2005. Patologi Hutan. Yogyakarta: Gadjah Mada University Press.

Wiryadiputra S. 2007. Epidemi penyakit tumor pada sengon (Paraserianthes falcataria) di Jawa Timur, Indonesia. Jurnal Ilmu Kehutanan (1):31-38.

Wood AR. 2012. Uromycladium tepperianum (a gallforming rust fungus) causes a sustained epidemic on the weed Acacia saligna in South Africa. Australian Plant Pathology 41(3): 255-261. http://dx.doi.org/10.1007/ s13313-012-0126-6. 